\title{
The Role of Maqasid Al-Shariah and Maslahah in Ethical Decision Making: A Study of Professionals in Indonesia
}

\author{
Sudarmawan Samidi ${ }^{1 *}$, Mohammad Faby Rizky Karnadi ${ }^{2}$ \\ Dety Nurfadilah ${ }^{3}$ \\ 1,3 Faculty of Economics, Universitas Krisnadwipayana, Jakarta 13077, Indonesia \\ 2 Sekolah Tinggi Manajemen Ipmi, Jakarta 12750, Indonesia
}

\begin{abstract}
A B S T R A C T
Ethical behavior is very important for every professional to ensure that the business will sustain for a long time and gain profitable. The present study is aimed at understanding the importance of Maqasid Al-Shariah and Maslahah in making ethical decisions among executive professionals in Indonesia. In view of this, the research analyse the practitioners' perception about the concept of Maqasid Al-Shariah and Maslahah in making ethical decisions, and analyse the relationship between their understanding of the concept and ethical decisions. Qualitative research method is used to collect a data from seven executive professionals from different industry and working experiences. This study used in-depth and intensive semi-structured interview. The finding showed that majority of respondents are not familiar with the concept of Maqasid Al-Shariah and Maslahah, although they proved that their current practice actually has been part of this concept.
\end{abstract}

A R T I C L E I N F O

\section{Keywords:}

Maqasid Al-Shariah,

Maslahah,

Ethical decision making,

Business Leaders.
*Correspondent Email:

sudarmawansamidi@unkris.ac.id

Copyright (C) 2017Authors. This is an open access article distributed under the Creative Commons Attribution License, which permits unrestricted use, distribution, and reproduction in any medium, provided the original work is properly cited.

\section{INTRODUCTION}

In the era of dynamic and uncertainty market, business sectors are significantly increasing very hard to keep integrity and competitiveness scale. The concept of competitiveness of the competency approach is based on conceptual model which is developed to link the characteristics of small and medium-sized enterprises ( $\mathrm{SME}^{\prime}$ ) owner-managers also their firm's performance altogether.

Most recently, all business leaders had some troubles with their daily activity in terms of management that they use to implement, especially in Multinational Corporation. Somehow, they did 
not realize that the way of making business decision was not so totally correct. In which, the result of decision they made is barely volatile at the end of the day, unless they already knew of what predictions were going to be occurred. Especially when someone is attempting to involve prioritization in terms of potential competing projects for limited resources. Besides, Maqasid AlShariah encompasses with different values toward any actions and deeds which are embedded in Islamic prioritization.

According to Al-Qardawi(2000), the importance and urgency from the Sharia's point of view, each matter can be easily prioritized and solved as long as the status is still correct. In a way, fiqh or Islamic Jurisprudence is all about prioritization as each matter can be categorized into the main five values, such as obligatory (Wajib), recommended (Mandub), permissible (Mubah), reprehensible (Makruh), and the last one is forbidden (Haram).

The Maqasid Al-Shariah in business alignment consists of four constructs, such as competitive scope, organizational capabilities, entrepreneurial competencies, and performance index. The main focus of business category is the way of conducting tasks that is linked toward different competency areas with other constructs of competitiveness which is based on Shari'ah objectives. In which, the propositions related to these relationships are truly made. So, the model suggests further research in the different competency areas, inter-industrial comparisons, and validating studies.

The primary objective of the study is to explore to extent to which practitioners understand the concept of Maqasid Al-Shariah and Maslahah in making ethical decisions, and whether there is a relationship between their understanding of the concept and ethical decisions.

The study is organized into six sections. Section one captures the introduction, section two highlights the review of literature, section three discusses the methodology employed in this study, section four captures the analysis and discussion of findings, section five highlights the conclusion and directions for future research.

\section{LITERATURE REVIEW}

The Concept of Maqasid Al-Shariah and Maslahah According to Al-Ghazali (1937), the objective of the Shari'ah is to promote the well-being of all mankind, which lies in safeguarding their faith (din), their human self (nafs), their intellect (aql), their posterity (nasl) and their wealth (mal). Whatever ensures the safeguard of these five serves public interest and is desirable. The late Islamic jurists such as Ibn 'Ashur has defined Shari'ah objectives as "the observed meanings and wisdoms in every Shari'ah rulings or most of them, whereby their observations prove that they are not specific to a type of Shari'ah rulings," (Ibn 'Ashur, 1978).

Based on the concept of Maslahah, projects, additionally, could also be classified into five categories. These five categories are related to the protection, improvement and amelioration of Man's five basic elements namely, religion, life, mind, offspring and wealth (Al-Masri, Rafiq Yunus, 1999). However, these five elements are not equal in importance. Some are more important than others, but each of them is essential. These elements, in order of priority according to the Malikiyyah and the Shafiiyyah, are (Al-Zuhayli, 1998). Such as: Religion (Din), Life (Nafs), Mind (Aql), Offspring (Nasab), Wealth (Mal).

Maslahah is a juristic device used in Islamic legal theory to promote the public good and prevent social evil or corruption. Its plural masalih, means "welfare, interest, or benefit." Literally, maslahah is defined as seeking benefit and repelling harm. Maslahah and manfa'ah (benefit or utility) are treated as synonyms. However, manfa'ah is not a technical meaning of maslahah, which Muslim jurists define as seeking benefit and repelling harm, as directed by God or the Shari’ah. Al-Shatibi, closely following al-Ghazzali's taxonomy, defines maslahah in his Al-Muwafaqat as a principle that concerns the subsistence of human life, the completion of one's livelihood, and the acquisition of what his/her emotional and intellectual qualities require of him/her in an absolute sense. He further classifies maslahah into three categories: daruriyat 
(the essentials), hajiyat (the complementary), and tahsiniyat (the embellishments). These categories are briefly discussed below:

a. Daruriyat: The essentials are the self-interests upon which people essentially depend, such as faith, life, intellect, posterity, and wealth.

b. Hajiyat: The complementary interests supplement the essentials and refer to those interests that, if neglected, would lead to hardship but not to the total disruption of life's normal order.

c. Tahsiniyat: The embellishments refer to those interests that, if realized, would lead to refinement and perfection in the customs and conduct of people at all levels of achievement.

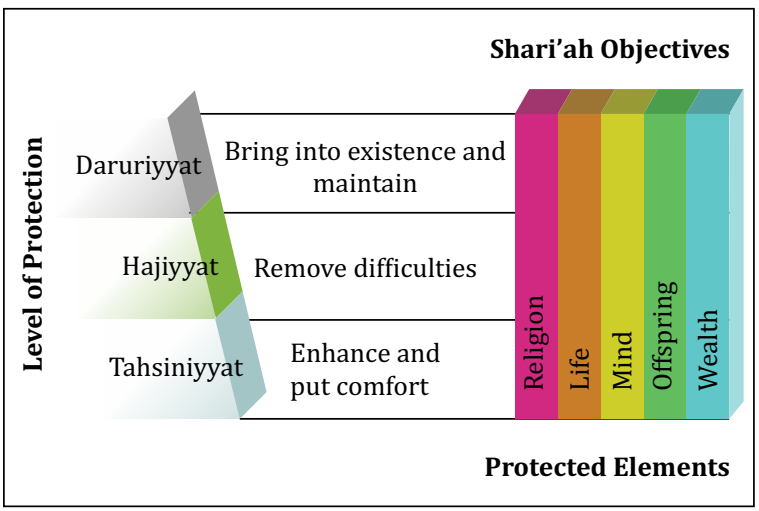

Source: Dasuki \& Abdullah. (2007), Jalil, A. (2011)

Figure 1. The Relationship between the Maqasid Al-Shariah and Maslahah Concept

The Shari ah's uppermost objectives rest within the concepts of compassion and guidance, which seek to establish justice, eliminate prejudice, and alleviate hardship by promoting cooperation and mutual support within the family and society at large. Both of these concepts are manifested by realizing the public interest that Islamic scholars have generally considered to be the Shari'ah's allpervasive value and objective that is, for all intents and purposes, synonymous with compassion.

\section{Ethical Decision Making}

Ethical decision making enables organizations to maintain and sustain competitiveness and competitive advantage. Mitchell et al. (2016) argued that pluralism in ethical decision making occurs in hybrid enterprises that aim for profit and social ends. Firms aim to achieve multiple objectives for diverse stakeholders. For profit objectives meant for business stakeholders. In terms of social objectives, more diverse stakeholders. The interenterprise stakeholder agency framework is necessary to support multi objective of company.

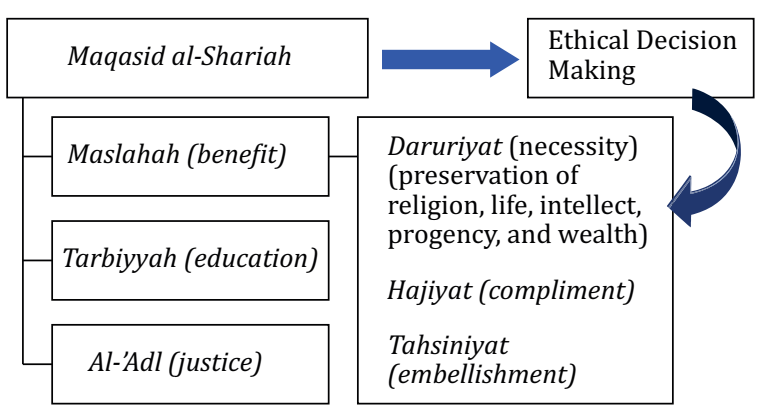

Source: Sarif, S.M., Ismail, Y., Azan, Z. (2017)

Figure 2. The effect of Maqasid al-Shari'ah and Maslahah concept in ethical decision.

\section{METHODOLOGY}

The study employs qualitative method to explore their understanding towards the concept of Maqasid Al-Shariah and Maslahah and the relationship between their understanding and their practice of making decision. The areas of concerned in this study include the basis practice of decision making in the enterprises.

Miles and Huberman (1994) argued that qualitative method is appropriate to examine complex and difficult contexts of study because they can put the situations in question into the right perspective. In addition, the reason to use qualitative method is to allow for more information which cannot be obtained through survey (Miles \& Huberman, 1994; Patton, 2002). Therefore, Marshall and Rossman (1999) recommended to use this method which enable researchers to ask more questions in order to explore the context of the study in greater detail.

The first section of this study focused on understanding the perception of respondents about Maqasid Al-Shariah and Maslahah in making decision. The second section focused on investigating as to what extent the practitioners understand the relationship between their understand about this concepts and their practice on making decision. 
This study obtained the results through in-depth and semi structure interview that was taken by interviewing seven respondents coming from various leadership backgrounds. Moreover, all data will be observed by researchers and the results will be transformed into clear explanations.

\section{FINDINGS AND DISCUSSIONS}

Perspective towards Maqasid Al-Shariah and Maslahah on Decision Making

In the first objective, Majority of respondents are not really understood the concept of Maqasid Al-Shariah and Maslahah due to the unfamiliar words, but after the explanation of this concept, they seem to realize that their current practice in making a decision is part of this concept.

According to IF1 and IF3, the concept of Maqasid Al-Shariah and Maslahah is something new for me. Although, it has some connections between managerial activities and religious belief, I think my current decision making has follow this concept.

IF4 agreed that the combination between managerial activities and religious belief has great impact for the company's value because it help them to set a boundaries between ethical and unethical behavior. Therefore, every top executive should understand this concept before making an important decision.

However, IF7 and IF2 argued that this concept should be separated from managerial activities because it is not relevant and it is not suitable for business. The firm's objective is to maximize profit, while this concept is make ethics as the first choice.

\section{There is a Relationship between their Understanding of the Concept and Ethical Decisions}

According to IF1, the importance of ethical decision that emphasized on value that people possess need to be explored. The IF1 said:

Ethical decision is very important because it is a basis for us to evaluate every decision taken. Absolutely, there is an intersection between every decision. Frankly speaking, it is difficult to differentiate between ethical decision and unethical decision making because there is no boundary or an existence of grey area between both sides. Some decision has a biased meaning, while others are more straightforward or easy to figure out. So, we need to identify which part are we living and to be adapted to the values we hold. We should have value because it will guide us.

The influence of visual or role model has shaped the IF1 to value the impact of any decision for the basics ethical conduct. Therefore, the IF1 only used sort of theoretical decision-making approach that always emphasized on consequences for uncertain ethical decision. In which, the role of Maqasid Al-Shariah provided the quantum of decision based on Maqasid Al-Shariah in the terms of education.As for the IF2, a proper discussion based on Shari'ah

Respondent's Information

Table 2. Informants' Brief Profile

\begin{tabular}{|c|c|c|c|}
\hline Code & Principal Business & Position & Working Experience \\
\hline IF1 & Higher Education & Executive Director & 17 years \\
\hline IF2 & Supply Chain Consulting & Talent Acquisition Director & 26 years \\
\hline IF3 & Online Services & Senior Advisor & 21 years \\
\hline IF4 & Asset Management & President Director & 25 years \\
\hline IF5 & Marketing \& Database Research Consulting & Vice President of Human Resource & 20 years \\
\hline IF6 & Media, Telco, \& I.T Solutions & President Commissioner & 27 years \\
\hline IF 7 & Mail \& Logistics & &
\end{tabular}

*IF: Informant 
approach (Musyawarah) influenced him to make ethical decision. In which, the IF2 stated:

There was a time where for the first time back in RGF recruit, we had to develop a performance improvement program for low performers back when I was a country general manager position in 2015. Because I felt that this critical decision I had to be discussed and Musyawarah among my 5 leaders, we gathered up by doing Musyawarah for the best practice. The result was we agreed on certain factors of the PIP to be successful like achieving target, KPI's on a certain time period.

The decision made by IF2 to be one of SME's leaders has been the practice ('Amal) that being repeated consistently ('Amal Soleh Bi Al Istiqamah) in a more likely close to justice (Al-'Adl). The performance issue of the employees has taken the IF2 into more Maslahah by doing an exact discussion (Musyawarah) to other line managers and board of directors that has impact to the relationships with all stakeholders.

Ethical principles have been always valuable rather than regulation. In which the IF3 stated his answer:

Business decision should be always based on ethical principle. Sometimes ethics is not represented or covered by the regulation. It's beyond the regulation. Business leaders who will always considered an ethical business decision are embedded in their heart. They understand that they will be asked his/her responsibility on every single decision they made in the judgment day.

According to the IF3 emphasized on heart as the basis for ethical principle and business decision which more likely to implement Daruriyat (necessity) as of theoretical decision-making approach. So, the relatedness on ethical business decision is embedded in the heart of business leaders.

The influence of visual model has formed the IF4 to value of the significance of any action and decision are not just for individual (fardy) but also the society (jama'ie).

There are 3 ethical things that $i$ ever faced, first, my products are services and data. There are ethical issues that $i$ faced up. Firstly, if there is some data that is played out, that means it disperses all industries. Because those data are used to make decisions. If there is anything wrong or deliberately blamed, the inputs to make decision is also wrong. So, the decision can lead to a fatal error which the large investments can just disappear. So, it's all up to a very guarded ethical conduct. Secondly, as a consultant who on the client side is a tender both private and government sector. From the several tenders, many stakeholders are trying to negotiate according to the standard operating procedure based on the business ethics that is being applied. But if $i$ choose with bribing system, then the implication to the data is also wrong so from the methodology also wrong so make it cheaper. So, I would better go back to the first ethical question. Because the ethical conditions are not easy to deal with.

The IF4 still used linear decision-making approach that always emphasized on consequences and impacts in terms monetary and tangible terms. According to the IF4, the impact on data and services are necessary. The role of Maqasid AlShariah provided the quantum of decision based on Maqasid Al-Shariah in terms of Maslahah.

In the term used by the Informant 5 is the impact to the key stakeholders and how that could make the social enterprise continuously relevant in the competitive world. Integrity has been always louder than a word (kalam). The IF5 added his statement:

When we have participated in a tender within a company, when we participate in the tender of some of its tender participants it invites us to speak outside. He said "Sir, please just give up, then we are going to give you fees, can you do that? so we can arrange it but you have to succumb as a comparison". I replied "With all due respect, I better not to participate in the tender related to the tender is set so, because those does not match with my ethics. Because on my side is winning, we are succumbing rather than doing badly. Because everything or sustenance that has been given from Allah, if it is belonging to our right, that means anyone cannot take it away. 
But if it doesn't, they will never get it. Better to play sportsmanship with truth and integrity. If we lost, it does not matter for us. But the fact was we won. After we won, it turns out the tender committee hopes the party from our side did not win. So, if there is another tender, we are no longer invited.

The feedback from the IF5 is related to consequences factor as Maqasid Al-Shariah inputin ethical decision making. There is a significant value of consequences in shaping ethical consideration. Such behavior has long lasting impact (Bazerman \& Sezer, 2016).

The ethical experience that the IF6 gone through has been memorable in terms of Maslahah to the people in terms of basic needs such as life and intellect. In addition, the objective (al-Ghayyah) of the social activity has been grounded on humanitarian (Al-hurriyyah Al-Insaniyyah). Figure 4. illustrates the impact of Maqasid Al-Shariah on ethical decision making at IF6. Moreover, the connectedness of intelligences has more different approaches but still in Shari'ah area, the Respondent did not realize that he is actually already implemented Shari'ah Objectives. In which the IF6 said:

As human beings, we have been granted by god with 4 intelligences. First is the emotional intelligence, the second is the intellectual intelligence, the third is spiritual intelligence, and the fourth is usually the people mention physical potion, but according to myself, it is actually execution potion. From the four of intelligences, $i$ utilize that the intelligences to make decision. So, there is something that needs to be solved, especially in business decisions, whether we take it or not? So first of all, I feel like whether the business is a good opportunity or not. Passionately, this is going to be profitable emotionally, but it's okay in emotional potion, we have to admit that we as human being must be excitement. But in intellectual we have to analyze. What's the risk at all? If we take this opportunity in terms of everything, it is beneficial or disadvantageous. After we see, it turns out many benefits than the negative instead. But there is a third filter, Spiritual. So spiritual is not talking about the benefits or negatives, but talk about right or wrong. And that checks through our conscience. If we do that, can we have sleep well or not? Lastly, once we know all of the three have been analyzed based on the intelligences, but hold on. Do not be unethical, for example like in a business at a massage parlor there is some kind of uncertaintyindicator.

In addition, the extension of social work included value and learning process. The IF6 said:

Lastly, we choose the name of execution. Execution inside man has free will to choose. For example, like if we decide to not proceed that kind of business. Due to our spiritual and ethical neglect which are due to our own choice. Not just because of coercion from people, nor any other situation but from our own choice. If we analyze something from emotional, intellectual, and spiritual perspectives are good. It's fine to take decision. Despite of finally having a problem, at least we have made a decision. Therefore, we have to fight for it until we reach the goals.

According to the IF7, the extension of social work included trustworthy and learned people. The IF7 said:

Unethical conduct that ever happened was since we had certain products. Then, the products were about to be released into the market. There are two ways, namely through third parties. Then they sell again to the market. One time there is one of the directors who had thought "sir we can just activate it first", so sim card is already given which is still not active, then we sell to the market. Because it is still not active yet which the selling process is more difficult. If we activated it first, then sell it at a cheaper price, then the market buys our products. So within a month, the market must do selling. Otherwise we all will die. After that, we kind of force the market to buy from us then forced to sell it. Then, the activation is also faster. At the first time, i agreed to sell for 600 thousand rupiah. Fitted right executed, it seems like sales turnover is sold so quickly within a month. So, some parties are addicted to making it. So within 2 months later, almost 2.1 million 
Table 3. Summary of Informants' Feedback

\begin{tabular}{|c|c|c|}
\hline Code & Main Points & Key values \\
\hline IF 1 & $\begin{array}{l}\text { Ethical decision need to be identified by the values that can be embraced to maintain } \\
\text { code of conduct to help making a proper decision in businesses. }\end{array}$ & $\begin{array}{l}\text { Code of Conduct, } \\
\text { Proper Decision }\end{array}$ \\
\hline IF 2 & $\begin{array}{l}\text { The most important thing in business is the ethics which will better lose with other } \\
\text { competitors rather than succeed but unethical. }\end{array}$ & $\begin{array}{l}\text { Unethical, Lose with } \\
\text { other Competitors }\end{array}$ \\
\hline IF 3 & $\begin{array}{l}\text { Critical decision in terms of developing performance improvement program for low } \\
\text { performers is needed be discussed by Musyawarah for the best practice. }\end{array}$ & $\begin{array}{l}\text { Critical Decision, } \\
\text { Musyawarah }\end{array}$ \\
\hline IF 4 & $\begin{array}{l}\text { Business decision is beyond the regulation which will need to be considered by the } \\
\text { business leaders as an ethical principle for those who have spiritual values embedded. }\end{array}$ & $\begin{array}{l}\text { Business Decisions, Spiritual } \\
\text { Values Embedded }\end{array}$ \\
\hline IF 5 & $\begin{array}{l}\text { Data is very important to be considered to know because the only firms can make } \\
\text { decision is with completed data to avoid risk upon any stakeholder's demand. }\end{array}$ & Data, Risk \\
\hline IF 6 & $\begin{array}{l}\text { There are four intelligences that people should possess especially in making ethical } \\
\text { business decision, such emotional intelligences, intellectual intelligences, spiritual } \\
\text { intelligences, and execution intelligences }\end{array}$ & Four Intelligences \\
\hline IF 7 & $\begin{array}{l}\text { Unethical conduct is occurred when the process of selling products are not based on } \\
\text { procedure which BODs as a whole are given by verbal warnings. }\end{array}$ & $\begin{array}{l}\text { Procedure, Verbal } \\
\text { Warnings }\end{array}$ \\
\hline
\end{tabular}

in the form of sim card and as if our customer increases. And then after six months in the terms of forced sales it was discovered that it was not the real customers which means they were all liars. In the end, the case is followed up by the internal audit that there are procedural errors and business ethics. Until then, from the BODs as a whole are given kind of verbal warnings.

In the term used by the IF7 the key stakeholders and how that could make the social enterprise continuously relevant in the competitive world. Figure 7 depicts the significance of Maqasid AlShariah on ethical decision making at IF 7.

\section{CONCLUSION AND DIRECTION FOR FUTURE RESEARCH}

Based on the results of the study the impact can be observed in the application of Maqasid Al-Shariah into enhancing the wellness, welfare, and wellbeing of company and the key stakeholders. Therefore, the entrepreneurs also have to think the well-being of the society first before think about the profit that would the entrepreneur gain. Highly profit that the professionals get would be nothing if its harm other people.

Furthermore, in order not to harm others, every professionals must analyze the concept of Maslahah to represent Islamic values before showing the assessment of the projects analyzed. By following the Shari'ah, the business would be barakah and have a long successful career because Maqasid AlShariah would led the practitioners and business professionals to decide a good decision which would be benefit for everyone and by doing Maslahah every professionals could decrease the crucial conception from the society and build a good image of the business thus it would affect the ethical decision of business people to consider about the welfare and the well-being of people. Maqasid Al-Shariah are inclined towards preserving the nature, people, and wealth.

By protecting the environment, professionals should also maintain their resources from earth to take care of the sustainability of the business thus the business would gain much profit. Beside it by protecting the environment, the professionals also contributed to protect the life of human and all of living things because the symbol of Islam is Rahmatan Lil 'Aalamin which means that grace for the whole of nature. Furthermore, some business decision makers realized the situation. As additional, volunteerism factor also served as Maqasid Al-Shariah input in ethical decision making. 


\section{RE F ERENCES}

Al-Ghazali, M. (1937). Ihya' 'Ulum al-Din. Cairo: al-Maktabah al-Tijariyyah al-Kubra.

Al-Masri, Rafiq Yunus. (1999). Usul al-Iqtisad al-Islami. Bayrut: Dar Al-Shamiyyah.

Al-Qardawi, Yusuf. (2000). Al-Siyasah al-shar'iyyah fi daw'i al-nusus al-Shari'ah wa maqasidiha. Bayrut: Mu'assat Al-Risalah.

Al-Zuhayli, Wahbah. (1998). Usul al-fiqh al-Islami, (2nd ed.). Dimashq: Dar Al-Fikr.

Dusuki, A. W., \& Abdullah, N. I. (2007). Maqasid al-shari'ah, Maslahah and corporate social responsibility. The American Journal of Islamic Social Sciences (AJISS), 24(1), 25-45.

Jalil, A. (2011). The Significances of Maslahah Concept and Doctrine of Maqasid (Objectives) Al-Shari'ah in Project Evaluation. The Journal of Muamalat and Islamic Finance Research (JMIFR), 3(1), 171-202.

Marshall, C., \& Rossman, G. B. (1999). Designing qualitative research, (3rd ed.). Thousand Oaks, CA: Sage.

Miles, M. B., and Huberman, A. M. (1994). Qualitative Data Analysis: An Expanded Sourcebook (2nd Ed.). Thousand Oaks, Ca: Sage Publications.

Mitchell, R. K., Weaver, G. R., Agle, B. R., Bailey, A. D., \& Carlson, J. (2016). Stakeholder agency and social welfare: Pluralism and decision making in the multi-objective corporation. Academy of Management Review, $41(2), 252-275$.

Patton, M. Q. (2002). Qualitative Research and Evaluation Methods. Thousand Oaks, Ca: Sage Publications.

Sarif, S.M., Ismail, Y., Azan, Z. (2017). Effects of Maqasid Al-Shariah for Ethical Decision Making Among Social Entrepreneurs. Journal of Islamic Management Studies, 1(1), 1-14. 